Prepared in cooperation with the City of Columbus, Department of Public Utilities, Division of Water

\title{
Groundwater Levels and Water Quality During a 96-Hour Aquifer Test in Pickaway County, Ohio, 2012
}

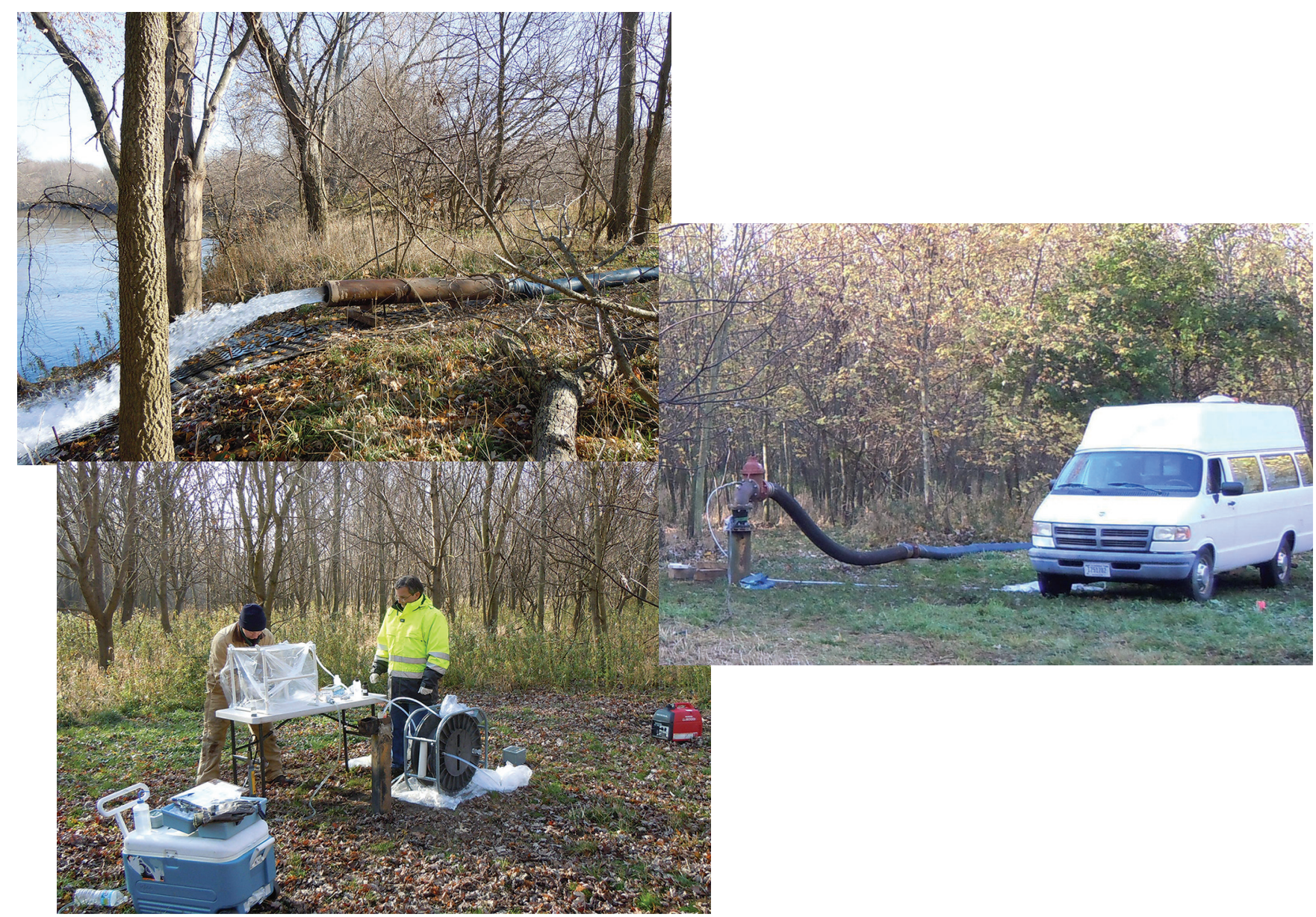

Scientific Investigations Report 2014-5040 


\section{Cover images:}

Top: Discharged water from the pumping well (PW) being directed into the Scioto River on November 15, 2012. (Photograph courtesy of Robert Andrews, City of Columbus.)

Bottom: U.S. Geological Survey scientists collecting a water sample from monitoring well P3 on November 16, 2012. (Photograph courtesy of Robert Andrews, City of Columbus.)

Right: Sample-collection equipment installed on the PW at the study area in Pickaway County, Ohio, on October 25, 2012. (Photograph courtesy of Robert Andrews, City of Columbus.) 


\section{Groundwater Levels and Water Quality During a 96-Hour Aquifer Test in Pickaway County, Ohio, 2012}

By Ralph J. Haefner, Donna L. Runkle, and Brian E. Mailot

Prepared in cooperation with the City of Columbus, Department of Public Utilities, Division of Water

Scientific Investigations Report 2014-5040 


\title{
U.S. Department of the Interior \\ SALLY JEWELL, Secretary
}

\section{U.S. Geological Survey \\ Suzette M. Kimball, Acting Director}

\author{
U.S. Geological Survey, Reston, Virginia: 2014
}

For more information on the USGS - the Federal source for science about the Earth, its natural and living resources, natural hazards, and the environment, visit http://www.usgs.gov or call 1-888-ASK-USGS.

For an overview of USGS information products, including maps, imagery, and publications, visit http://www.usgs.gov/pubprod

To order this and other USGS information products, visit http://store.usgs.gov

Any use of trade, firm, or product names is for descriptive purposes only and does not imply endorsement by the U.S. Government.

Although this information product, for the most part, is in the public domain, it also may contain copyrighted materials as noted in the text. Permission to reproduce copyrighted items must be secured from the copyright owner.

Suggested citation:

Haefner, R.J., Runkle, D.L., and Mailot, B.E., 2014, Groundwater levels and water quality during a 96-hour aquifer test in Pickaway County, Ohio, 2012: U.S. Geological Survey Scientific Investigations Report 2014-5040, 16 p., http://dx.doi.org/10.3133/sir20145040. 


\section{Contents}

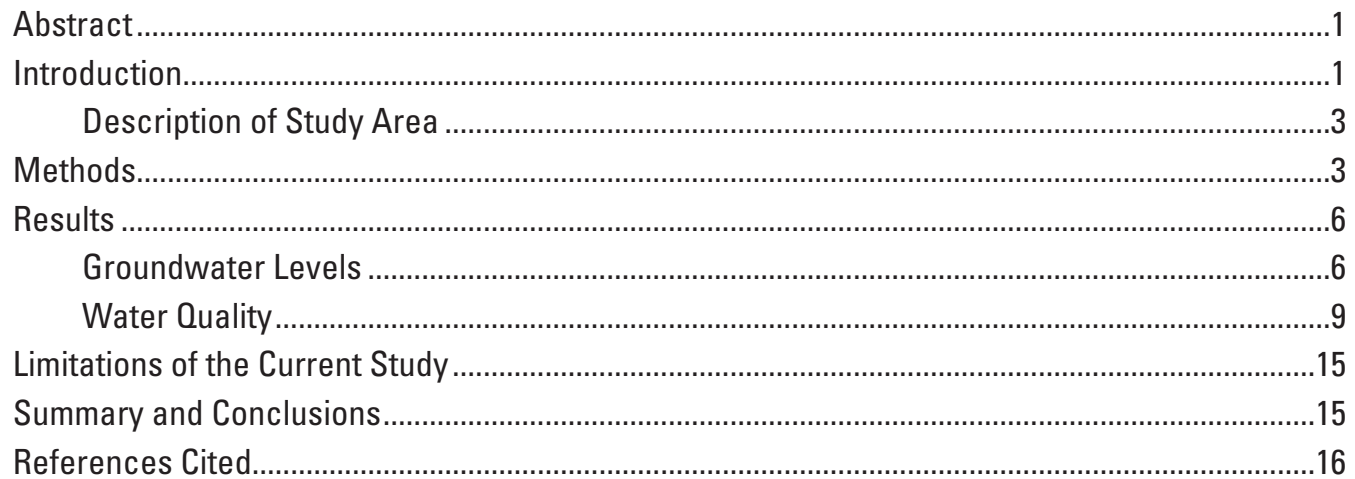

\section{Figures}

1. Map showing data-collection sites at the study area in Pickaway County, Ohio .............2

2. Hydrograph showing groundwater and surface-water level altitudes at the study area and at sites upstream of the study area in Pickaway and Franklin Counties, Ohio, October and November 2012

3. Maps showing water levels at the study area, Pickaway County, Ohio, October and November 2012. A, Before the 96-hour aquifer test.

$B$, At the end of the 96 -hour aquifer test. . .8

4. Time-series plots of rainfall and air temperature at the Port Columbus Airport and water quality in the Scioto River, Ohio, October and November 2012

5. Graphs showing water-quality results for temperature, chloride, bromide, chloride-to-bromide ratio, and strontium for samples from the pumping well and the Scioto River, Pickaway County, Ohio

6. Graphs showing water-quality results for orthophosphate, nitrate, $\delta^{15} \mathrm{~N}$ in nitrate, and $\delta^{18} 0$ in nitrate for samples from the pumping well and the Scioto River, Pickaway County, Ohio

7. Graph showing stable-isotope ratios of nitrogen and oxygen in nitrate from water samples obtained before and during the aquifer test, Pickaway County, Ohio, October and November 2012 


\section{Tables}

1. Well-construction details for wells at the study area, Pickaway County, Ohio ................4

2. Water-level measurement and sample-collection dates associated with the aquifer test, Pickaway County, Ohio, October and November 2012 .................................5

3. Water levels in wells at the study area, Pickaway County, Ohio......................................6

4. Results of water-quality analyses from before and during the aquifer test, Pickaway County, Ohio, October and November 2012. [Available as a downloadable Microsoft Excel file at $h$ ttp://pubs.usgs.gov/sir/2014/5040/table/sir2014-5040_table4.x/sx.]

\section{Conversion Factors and Abbreviations}

Inch/Pound to SI

\begin{tabular}{|c|c|c|}
\hline Multiply & By & To obtain \\
\hline \multicolumn{3}{|c|}{ Length } \\
\hline inch (in.) & 2.54 & centimeter $(\mathrm{cm})$ \\
\hline inch (in.) & 25.4 & millimeter (mm) \\
\hline foot $(\mathrm{ft})$ & 0.3048 & meter $(\mathrm{m})$ \\
\hline mile (mi) & 1.609 & kilometer $(\mathrm{km})$ \\
\hline \multicolumn{3}{|c|}{ Flow rate } \\
\hline cubic foot per second $\left(\mathrm{ft}^{3} / \mathrm{s}\right)$ & 0.02832 & cubic meter per second $\left(\mathrm{m}^{3} / \mathrm{s}\right)$ \\
\hline gallon per minute (gal/min) & 0.06309 & liter per second $(\mathrm{L} / \mathrm{s})$ \\
\hline \multicolumn{3}{|c|}{ Infiltration rate } \\
\hline $\begin{array}{l}\text { gallons per day per foot squared } \\
\text { per foot }\left[(\text { gal } / \mathrm{d}) /\left(\mathrm{ft}^{2}\right) / \mathrm{ft}\right]\end{array}$ & 133.67 & $\begin{array}{l}\text { liter per day per meter squared per } \\
\text { meter }\left[(\mathrm{L} / \mathrm{d}) /\left(\mathrm{m}^{2}\right) / \mathrm{m}\right]\end{array}$ \\
\hline \multicolumn{3}{|c|}{ Hydraulic conductivity } \\
\hline foot per day $(\mathrm{ft} / \mathrm{d})$ & 0.3048 & meter per day $(\mathrm{m} / \mathrm{d})$ \\
\hline $\begin{array}{l}\text { gallon per day per foot squared } \\
{\left[(\mathrm{gal} / \mathrm{d}) / \mathrm{ft}^{2}\right]}\end{array}$ & 0.0408 & meter per day $(\mathrm{m} / \mathrm{d})$ \\
\hline \multicolumn{3}{|c|}{ Transmissivity* } \\
\hline foot squared per day $\left(\mathrm{ft}^{2} / \mathrm{d}\right)$ & 0.09290 & meter squared per day $\left(\mathrm{m}^{2} / \mathrm{d}\right)$ \\
\hline gallon per day per foot $[(\mathrm{gal} / \mathrm{d}) / \mathrm{ft}]$ & 0.01242 & meter squared per day $\left(\mathrm{m}^{2} / \mathrm{d}\right)$ \\
\hline
\end{tabular}


Temperature in degrees Celsius $\left({ }^{\circ} \mathrm{C}\right)$ may be converted to degrees Fahrenheit $\left({ }^{\circ} \mathrm{F}\right)$ as follows:

${ }^{\circ} \mathrm{F}=\left(1.8 \times{ }^{\circ} \mathrm{C}\right)+32$

Vertical coordinate information is referenced to the North American Vertical Datum of 1988 (NAVD 88).

Horizontal coordinate information is referenced to the North American Datum of 1983 (NAD 83).

Altitude, as used in this report, refers to distance above the vertical datum.

*Transmissivity: The standard unit for transmissivity is cubic foot per day per square foot times foot of aquifer thickness $\left[\left(\mathrm{ft}^{3} / \mathrm{d}\right) / \mathrm{ft}^{2}\right] \mathrm{ft}$. In this report, the mathematically reduced form, foot squared per day $\left(\mathrm{ft}^{2} / \mathrm{d}\right)$, is used for convenience.

Specific conductance is given in microsiemens per centimeter at 25 degrees Celsius $(\mu \mathrm{S} / \mathrm{cm}$ at $\left.25^{\circ} \mathrm{C}\right)$.

Concentrations of chemical constituents in water are given either in milligrams per liter (mg/L) or micrograms per liter ( $\mu \mathrm{g} / \mathrm{L})$.

Abbreviated water-quality units used in this report: Chemical concentrations and water temperature are given in metric units. Concentrations of chemical constituents in water are given in units of milligram per liter ( $\mathrm{mg} / \mathrm{L}$ ) or microgram per liter $(\mu \mathrm{g} / \mathrm{L})$. A milligram per liter is a unit expressing the concentration of chemical constituents in solution as weight (milligram) of solute per unit volume (liter) of water. One thousand micrograms per liter is equivalent to 1 milligram per liter. For concentrations less than $7,000 \mathrm{mg} / \mathrm{L}$, the numerical value for milligrams per liter is the same as for concentrations in part per million.

$\delta$ (delta), as used in this report, refers to the stable-isotope ratio $\delta x=\left\{\left[R_{x}-R_{\text {std }}\right] / R_{\text {std }}\right\} * 1,000$, where $R_{x}$ and $R_{\text {std }}$ are the ${ }^{2} \mathrm{H} /{ }^{1} \mathrm{H}$ and ${ }^{18} \mathrm{O} /{ }^{16} \mathrm{O}$ values of the sample and reference standard. The value of $\delta$ generally is expressed in parts per thousand (\%o, or per mil). Per mil, as used in this report, is equivalent to parts per thousand relative to the standard.

\section{Abbreviations used in this report}

$\begin{array}{ll}\text { MCL } & \text { maximum contaminant level } \\ \mathrm{N} & \text { nitrogen } \\ \mathrm{O} & \text { oxygen } \\ \mathrm{OH} & \text { Ohio } \\ \mathrm{PW} & \text { pumping well } \\ \text { USGS } & \text { U.S. Geological Survey } \\ \delta^{15} \mathrm{~N} & \text { nitrogen-15 stable isotope } \\ \delta^{18} \mathrm{O} & \text { oxygen-18 stable isotope }\end{array}$





\title{
Groundwater Levels and Water Quality During a 96-Hour Aquifer Test in Pickaway County, Ohio, 2012
}

\author{
By Ralph J. Haefner, Donna L. Runkle, and Brian E. Mailot
}

\section{Abstract}

During October-November 2012, a 96-hour aquifer test was performed at a proposed well field in northern Pickaway County, Ohio, to investigate groundwater with elevated nitrate concentrations. Earlier sampling done by the City of Columbus revealed that some wells had concentrations of nitrate that approached 10 milligrams per liter $(\mathrm{mg} / \mathrm{L})$, whereas other wells and the nearby Scioto River had concentrations from 2 to $6 \mathrm{mg} / \mathrm{L}$. The purpose of the current test was to examine potential changes in water quality that may be expected if the site was developed into a public water-supply source; therefore, water-transmitting properties determined during a previous test were not determined a second time.

Before and during the test, water-level data and waterquality samples were obtained from observation wells while a test production well was pumped at 1,300 gallons per minute. Before the test, local groundwater levels indicated that groundwater was being discharged to the nearby Scioto River, but during the test, the stream was losing streamflow owing to infiltration. Water levels declined in the pumping well, in adjacent observation wells, and in a nearby streambed piezometer as pumping commenced. The maximum drawdown in the pumping well was 29.75 feet, measured about 95 hours after pumping began.

Water-quality data, including analyses for field parameters, major and trace elements, nutrients, and stable isotopes of oxygen and nitrogen in nitrate, demonstrated only small variations before and during the test. Concentrations of nitrate in five samples from the pumping well ranged from about 5.10 to $5.42 \mathrm{mg} / \mathrm{L}$ before and during the test, whereas concentrations of nitrate in five samples on or about the same sampling dates and times at a monitoring site on the Scioto River adjacent to the pumping well ranged from 3.46 to $4.97 \mathrm{mg} / \mathrm{L}$. Water from two nearby observation wells had nitrate concentrations approaching $10 \mathrm{mg} / \mathrm{L}$, which is the U.S. Environmental Protection Agency's Maximum Contaminant Level for nitrate. Analysis of isotopes of oxygen and nitrogen in nitrate indicated that the source of nitrate is most likely soil nitrogen and fertilizer, with some denitrification and (or) mixing with some manure and septic waste derived from upstream wastewatertreatment facilities.

\section{Introduction}

As the demand for potable water grows, the City of Columbus (hereafter the City) is challenged with finding additional, reliable sources of water. To meet this demand, the City purchased property in Pickaway County, Ohio (fig. 1), with the intent of installing public-supply wells. During fall 2012, the City performed an aquifer test at the location of a proposed public-supply well on the property (hereafter referred to as the study area). The purpose of the test was to document groundwater levels and groundwater quality as the City pumped a test production well (hereafter referred to as the pumping well (PW)) for 96 hours. Groundwater sampling done after the study area was purchased had shown nitrate concentrations in some monitoring wells near the U.S. Environmental Protection Agency's (EPA) Maximum Contaminant Level (MCL) of 10 milligrams per liter (mg/L; U.S. Environmental Protection Agency, 2013), whereas other wells and the nearby Scioto River had concentrations from 2 to $6 \mathrm{mg} / \mathrm{L}$ (Robert Andrews, City of Columbus, written commun.). If the City planned to install a public-supply well at this location, it was important to determine if continued pumping would influence the source(s) of water to the well, thereby potentially changing the water quality and, perhaps, the need for treatment. Similar issues related to elevated nitrate in groundwater have been documented in Ohio by the Ohio Department of Natural Resources (1995), Schumann and Pletsch (2006), and the Ohio Environmental Protection Agency (2008); thus, the approach and results of this study were intended to expand our local and regional understanding of nitrate sources and occurrence in groundwater.

In accordance with a long-standing cooperative agreement with the City, the U.S. Geological Survey (USGS) helped to plan, coordinate, and conduct the aquifer test. The USGS assisted the City in collecting data from several observation wells in close proximity to the PW, the nearby Scioto River, and a piezometer driven into streambed sediments. This report summarizes the data-collection approach and results of measurements of groundwater levels and water quality. 


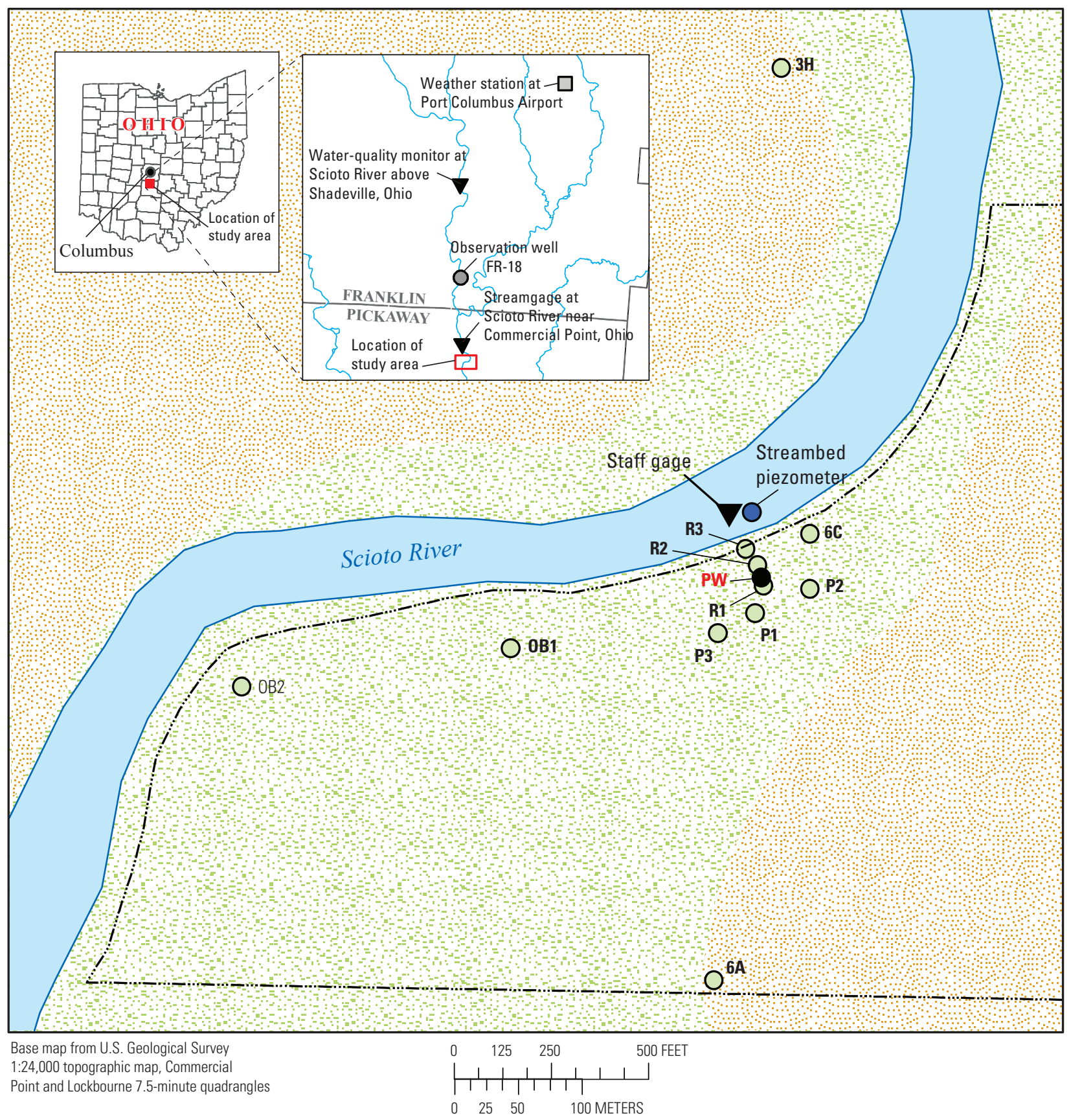

\section{EXPLANATION}

Land cover
$\quad$ Scrub / forested
$\quad$ Agricultural (corn and soybeans)

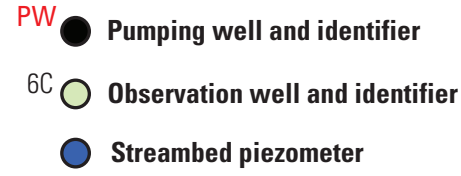

Staff gage or streamgage

Figure 1. Data-collection sites at the study area in Pickaway County, Ohio. 


\section{Description of Study Area}

The study area lies along the banks of the Scioto River in northern Pickaway County Ohio, approximately 14 miles (mi) south of the City (fig. 1). The geology of the site is characterized by glacial and alluvial sediments consisting of unconsolidated silt, sand, and gravel overlying shale and limestone of Devonian age. In the vicinity of the study area, the surficial silt, sand, and gravel are about 110 to 140 feet (ft) thick, and bedrock lies at an elevation of about $600 \mathrm{ft}$ (Bennett \& Williams Environmental Consultants, Inc., 2000). During a previous aquifer test done for the City during summer 1999 by Bennett \& Williams Environmental Consultants, Inc. (Bennett \& Williams Environmental Consultants, Inc., 2000), drawdown data were analyzed to estimate water-transmitting properties of the sand and gravel aquifer at the site (this analysis was not repeated during the aquifer test described in this report). Analysis of a step-drawdown test identified that a pumping rate of 1,300 gallons per minute (gal/min) was appropriate for a subsequent constant-rate aquifer test. Water levels in the PW during the constant-rate test responded immediately to pumping and drawdown in the PW at the end of the test was reported as $34.03 \mathrm{ft}$. Based on results of the test done by Bennett \& Williams Environmental Consultants, Inc. (2000), a pumping rate of $1,300 \mathrm{gal} / \mathrm{min}$ also was used in the aquifer test described in this report. Results of the previous analysis indicated two zones of different transmissivity, presumably the result of alluvial processes related to reworking of sediments in and around the Scioto River. As described by Bennett \& Williams Environmental Consultants, Inc. (2000, p. 60)...

“...The complexity of the depositional history is apparent in the cross-sections and is dominated by numerous cut and fill processes, characterized by alternating thin sequences that vary significantly between borings. The most prominent hydrogeologic feature of this site is the aquifer's lateral separation into two relatively distinct zones. These zones were first detected during installation of the observation well test pattern; sediments at P1, P2, and P3, particularly in the bottom portions of the aquifer, appeared to be finer and tighter than the sediments near the river at $\mathrm{R} 2$ and $\mathrm{R} 3 \ldots$... the borings nearest the river (R2, R3, and the test well [PW]) encountered the thickest sections of clean sand and gravel. Aquifer materials encountered along the parallel line of wells generally appear dirtier, consisting predominantly of silty sands and gravels with few thin clean sand and gravel zones. Overall the formation south of R1 appears less permeable, as evident by the tighter silt and clay matrix that forms a binder around the coarser sands and gravels."
Thus, the boundary between two zones of differing hydraulic characteristics is defined by a line roughly parallel to the south bank of Scioto River that runs through well R1 (which is less than $100 \mathrm{ft}$ south of the PW; fig. 1). This indicates that wells P3, P2, and P1 lie within the lower permeability zone, whereas wells R3, 6C, and the PW are in the higher permeability zone. Well logs and a geologic section included as figure 31 in the report by Bennett \& Williams Environmental Consultants, Inc. (2000) indicated that well R3 penetrated two layers of silty clay at depths of about 25 and $35 \mathrm{ft}$ (at elevations of about 652 and $642 \mathrm{ft}$, respectively), the shallower of which also is present in well R2, but not in any of the other wells, including the PW. The geologic section shows the clay layers as continuous layers beneath the Scioto River, but additional data confirming this were not available. Even though these wells are within the higher hydraulic conductivity zone described above, the presence of clay layers may influence the hydraulic connection between the river and underlying aquifer materials adjacent to wells R2 and R3.

In the zone near the river north of well R1, transmissivity was estimated at 90,500 gallons per day per foot [(gal/d)/ $\mathrm{ft}]$, or about 12,100 feet squared per day $\left(\mathrm{ft}^{2} / \mathrm{d}\right)$; the hydraulic conductivity was 1,667 gallons per day per foot squared [(gal/d)/ft² $]$, or about 225 feet per day (ft/d; Bennett \& Williams Environmental Consultants, Inc., 2000). In the zone south of well R1, the aquifer transmissivity was estimated to be about one-half of that near the river at $45,000(\mathrm{gal} / \mathrm{d}) / \mathrm{ft}$ (about $6,000 \mathrm{ft}^{2} / \mathrm{d}$ ). The aquifer storage coefficient computed for the entire area was 0.2 , and the vertical-to-horizontal ratio of hydraulic conductivity was 1:30. While continuously pumping at a rate of approximately $1,300 \mathrm{gal} / \mathrm{min}$, the infiltration rate from the river was estimated to be about 6 gallons per day per foot squared per foot $\left[(\mathrm{gal} / \mathrm{d}) /\left(\mathrm{ft}^{2}\right) / \mathrm{ft}\right]$. Bennett \& Williams Environmental Consultants, Inc. (2000) also estimate that 65 percent of the PW discharge was derived from "river diversion," which equates to the sum of intercepted flow into the river and induced infiltration from streamflow.

\section{Methods}

This study utilized existing wells (pumping and observation) to monitor groundwater levels and obtain groundwater samples for chemical analysis. All of the wells were installed by the City in the 1990s and were completed in unconsolidated sediments. Wells used in this study are shown in figure 1, and their construction details are listed in table 1. Prior to the onset of pumping, the USGS installed a staff gage and a streambed piezometer in the Scioto River approximately $125 \mathrm{ft}$ north of the PW (fig. 1). The screen length of the piezometer was $0.5 \mathrm{ft}$, and the tip of the streambed piezometer was driven approximately $2.5 \mathrm{ft}$ beneath the streambed. 
Table 1. Well-construction details for wells at the study area, Pickaway County, Ohio.

[USGS, U.S. Geological Survey; ID, identification; ft, foot; in., inch; na, not applicable; --, unknown; elevations are referenced to North American Vertical Datum of 1988 (NAVD 88); PW, pumping well]

\begin{tabular}{|c|c|c|c|c|c|c|c|}
\hline $\begin{array}{c}\text { Well } \\
\text { identifier } \\
\text { used in this } \\
\text { report }\end{array}$ & $\begin{array}{c}\text { USGS } \\
\text { local ID }\end{array}$ & $\begin{array}{l}\text { Land- } \\
\text { surface } \\
\text { elevation } \\
\text { (ft) }\end{array}$ & $\begin{array}{c}\text { Well } \\
\text { depth } \\
\text { (ft below } \\
\text { land surface) }\end{array}$ & $\begin{array}{l}\text { Casing } \\
\text { diameter } \\
\text { (in.) }\end{array}$ & $\begin{array}{c}\text { Screen top } \\
\text { (ft below } \\
\text { land surface) }\end{array}$ & $\begin{array}{c}\text { Screen } \\
\text { bottom } \\
\text { (ft below } \\
\text { land surface) }\end{array}$ & $\begin{array}{c}\text { Distance } \\
\text { to PW } \\
\text { (ft) }\end{array}$ \\
\hline \multicolumn{8}{|c|}{ Water levels measured and wells sampled by USGS } \\
\hline $6 \mathrm{C}$ & PK-236 ESW-6C & 673.14 & 63.1 & 4 & 53.0 & 63.0 & 164 \\
\hline P1 & PK-234 ESW-P1 & 672.50 & 57.0 & 2 & 42.0 & 57.0 & 84 \\
\hline P3 & PK-233 ESW-P3 & 672.71 & 60.5 & 2 & 50.5 & 60.5 & 167 \\
\hline PW & PK-228 ESW-PW1 & 672.91 & 74.0 & 12 & 64.0 & 74.0 & na \\
\hline R3 & PK-231 ESW-R3 & 672.48 & 70.0 & 2 & 55.0 & 70.0 & 84 \\
\hline \multicolumn{8}{|c|}{ Water levels measured and wells sampled by the City of Columbus } \\
\hline $3 \mathrm{H}$ & PK-238 SMITH-3H & 674.63 & 52.9 & 4 & 42.9 & 52.9 & 1,295 \\
\hline $6 \mathrm{~A}$ & PK-237 ESW-6A & 702.48 & 71.2 & 4 & -- & -- & 973 \\
\hline OB1 & PK-235 ESW-OB1 & 670.53 & 62.0 & 2 & 42.0 & 62.0 & 675 \\
\hline OB2 & PK-239 ESW-OB2 & 670.58 & 68.0 & 2 & 48.0 & 68.0 & 1,353 \\
\hline $\mathrm{P} 2$ & PK-232 ESW-P2 & 671.51 & 55.5 & 2 & 45.5 & 55.5 & 117 \\
\hline $\mathrm{R} 1$ & PK-229 ESW-R1 & 672.58 & 60.0 & 2 & 45.0 & 60.0 & 15 \\
\hline $\mathrm{R} 2$ & PK-230 ESW-R2 & 673.37 & 71.7 & 2 & 51.7 & 71.7 & 30 \\
\hline
\end{tabular}

${ }^{1}$ For the PW, water levels were measured by the City of Columbus; both the USGS and the City of Columbus obtained water-quality samples.

The USGS selected the PW and four observation wells to monitor water levels and collect water-quality samples at various intervals before, during, and at the end of the test. Water levels were measured in all wells before, during, and at the end of the test by calibrated electrical tape from measuring points surveyed to the top of each well casing. The City installed pressure transducers in these wells prior to the start of the test to continuously record water levels before, during, and after the aquifer test. The USGS installed a transducer in the streambed piezometer to record water levels within the shallow sediments of the Scioto River. Water levels were recorded hourly before the test, every minute during the test, and every 30 minutes after the test by the transducers installed in the observations wells and the streambed piezometer. Manual water-level measurements were made when the transducers were installed and on a daily basis throughout the duration of the test in accordance with procedures outlined in Cunningham and Schalk (2011). In the PW, the pressure transducer recorded water levels every 30 minutes prior to the start of the test and every 15 seconds during and after the test. Typically, recording intervals during aquifer tests are done on much shorter intervals (seconds or minutes); however, determination of aquifer properties was not an objective of this test, so longer recording intervals were deemed adequate. Elevations of the measuring points and land surface at each well were determined to the nearest hundredth of a foot relative to the North American Vertical Datum of 1988 (NAVD 88). This was accomplished by establishing elevations for two temporary survey marks with a global positioning system using a RealTime Network developed by the Ohio Department of Transportation. Elevation loops were surveyed between the central hubs to the wells using conventional survey equipment.

Data from two upstream streamgages and an observation well were selected for inclusion in this study (fig. 1) to compare local conditions with conditions at nearby long-term data-collection sites in similar hydrogeologic settings. The nearest streamgage operated by the USGS was "Scioto River near Commercial Point OH” (USGS site number 03229610), approximately 1.3 river miles $(7,000 \mathrm{ft})$ upstream from the study site, where stage was recorded on an hourly basis. Stage data are available through the USGS National Water Information System at USGS National Water Information System, http://waterdata.usgs.gov/nwis, using data-collection methods described in Sauer and Turnipseed (2010). Another streamgage approximately $6 \mathrm{mi}$ north of the study site was a water-quality monitoring site, "Scioto River above Shadeville OH" (USGS 
site number 03228039 ). Water-quality data (temperature, $\mathrm{pH}$, dissolved oxygen, specific conductance, and turbidity) were recorded on an hourly basis at this gage, but stage and discharge were not measured. The nearest observation well instrumented to collect continuous water-level data was about 5 mi north of the study site at well FR-18 (USGS site number 394956083002700 ). This well is $86.4 \mathrm{ft}$ deep, is screened within sand and gravel deposits of glacial and alluvial origin, and is within $200 \mathrm{ft}$ of the Scioto River.

Water-quality samples from the Scioto River, four observation wells (wells 6C, P1, P3, and R3), and the PW were obtained at the study site using methods described in the USGS National Field Manual (U.S. Geological Survey, variously dated). Water-quality constituents were selected to aid in the evaluation of changes (if any) in water chemistry during the period of the aquifer test and included field parameters, major and trace elements, nutrients, and stable isotopes of oxygen and nitrogen in nitrate. Field parameters were measured using a YSI 6920 5-parameter sonde in a flow-through chamber or a YSI 600XL 4-parameter sonde in a flow-through chamber and an external Hach 2100P turbidimeter. Analyses for major and trace elements (with the exception of bromide, chloride, and strontium) were done only on samples from the Scioto River and the PW before and at the end of the aquifer test. Additional analyses for bromide, chloride, and strontium were done on water samples taken from the PW throughout the test to determine if any of these elements - separate or together - could be used to detect waters derived from the river or from underlying bedrock. Water-quality samples were analyzed by USGS laboratories in Denver, Colorado, and Reston, Virginia using methods described in Fishman and Friedman (1989), Fishman (1993), Patton and Kryskalla (2003), and Coplen and others (2012). Estimated concentrations are provided for those analyses that have been positively identified at concentrations below the long-term method detection limit as described in Childress and others (1999).
Quality-control samples included one equipment blank sample to assess the potential for contamination of the sample introduced by the sampling equipment and one concurrent replicate sample to begin to quantify sampling variability. Analyses of quality-control samples were limited to nutrients, bromide, chloride, and strontium. One replicate sample was analyzed for isotopes of nitrogen and oxygen in nitrate.

The water-quality sampling strategy was established to obtain samples of groundwater and surface water within a few days before the onset of pumping and then again at selected time intervals throughout the 96-hour aquifer test. On October 22, 23, and 25, 2012 (and before the onset of continuous pumping), transducers were installed in the PW, observations wells, in the streambed piezometer, and within the Scioto River. During this period, water samples were obtained from the Scioto River, the PW, and observation wells $6 \mathrm{C}, \mathrm{P} 1, \mathrm{P} 3$, and R3. However, the aquifer test was postponed due to high-water conditions during October 24-November 1, 2012, related to 2.11 inches (in.) of rain from Hurricane Sandy that fell on and around Columbus, Ohio (National Oceanic and Atmospheric Administration, 2013). The aquifer test was postponed for about 2 weeks until field conditions for stream and site access were safe.

Table 2 shows the time line for measurements and waterquality sampling before and during the aquifer test. The PW was pumped at a rate of $1,300 \mathrm{gal} / \mathrm{min}$ starting at 1600 hours on November 12, 2012, and was pumped continuously at approximately the same rate through 1600 hours on November 16, 2012. Discharge from the PW was monitored by the City personnel for flow rate and field parameters including temperature, $\mathrm{pH}$, dissolved oxygen, and specific conductance. All pump discharge was directed through a pipe into the Scioto River approximately $300 \mathrm{ft}$ downstream from the PW.

Table 2. Water-level measurement and sample-collection dates associated with the aquifer test, Pickaway County, Ohio, October and November 2012. Shading indicates activity done on specified dates.

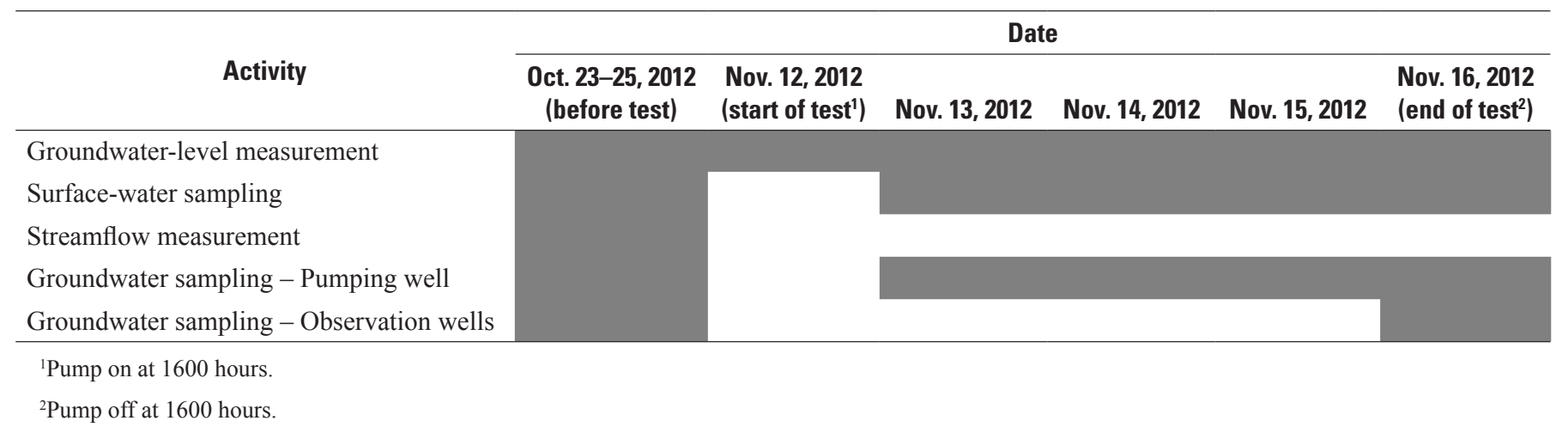




\section{Results}

Results of water-level measurements and water-quality sampling are provided to assess changes, if any, in sources of water to the PW before and during a 96-hour aquifer test. The water-level data are assessed only in terms of comparisons between results obtained before the onset of pumping and during the test. The water-quality data are examined with respect to differences observed between samples collected before and during the test, and also with respect to differences between water quality of groundwater and of the Scioto River. Additionally, data from an observation well and a water-quality monitor on the Scioto River several miles north of the site are compared to data collected at the site to determine if existing data-collection sites could be used as surrogates to monitor water levels and surface-water quality at the site.

\section{Groundwater Levels}

Groundwater-level data from the PW (furnished by the City) and from an offsite well FR-18 (available on-line through the Ohio Department of Natural Resources at http:// www.dnr.state.oh.us/water/waterobs/default.asp) are plotted in figure 2 along with data on water levels in the streambed piezometer and stream stage at the study area and at the upstream gage at "Scioto River near Commercial Point OH." Water levels in the PW declined immediately after pumping started on November 12, 2012. Drawdown in the PW stabilized to about 28 to $29 \mathrm{ft}$ within 2 minutes. Water levels in the PW and in the streambed piezometer show the influence of pumping and changes in stream stage. For the purposes of this report, drawdown includes the effect of changing stream stage at the site. The maximum drawdown in the PW from the initial water level in the well was measured at $29.75 \mathrm{ft}$, approximately 95 hours after the start of pumping. After about 180 minutes of pumping, water levels in the streambed piezometer started to decline. Since the stream stage varied as a function of time, drawdown in the streambed piezometer is described as the difference between stream stage and water level in the streambed piezometer. From figure 2, note that the maximum difference between the stream stage and water level in the streambed piezometer does not necessarily coincide with the lowest water level in the streambed piezometer. The maximum drawdown in the streambed piezometer was $2.29 \mathrm{ft}$, approximately 67 hours after the start of pumping. At the time of the maximum drawdown in the PW, the drawdown in the streambed piezometer was $2.18 \mathrm{ft}$.

Water levels in well FR-18 show a muted response to rainfall events in relation to other sites. Water levels in FR-18 began to rise on October 22, 2012 (before the rainfall associated with Hurricane Sandy began on October 24, 2012), and peaked towards the end of the storm on November 3, 2012. Reasons for the rise before the storm are unclear, but the data indicate that water levels in this well are subject to other hydrologic influences, and the use of groundwater levels from FR-18 as a surrogate for groundwater levels at the proposed supply-well site may be questionable. Additionally, well FR-18 is located about $500 \mathrm{ft}$ northeast of another City production well, which, according to the City records, was pumped from October 19, 2012 to October 22, 2012, at a rate of about 3,120 gal $/ \mathrm{min}$.

Water-level data from before the pumping began on October 23, 2012, and at the end of the test on November 16, 2012, are shown in table 3. Water-level contours developed from data measured in the pumping well and observation wells, the streambed piezometer, and a staff gage within the Scioto River for prior to and after the aquifer test are shown in figure 3. This figure also shows water-level data for the PW and other observation wells that were measured by the City and were furnished to the USGS (Robert Andrews, written commun., 2013). Prior to the test, groundwater-flow directions in the vicinity of the PW were towards the Scioto River, indicating that, in the stream reach examined in this study, the Scioto River was a gaining stream (a stream reach where groundwater contributes flow to surface water). Towards the end of the test on November 16, 2012, local groundwaterflow directions that were previously towards the river were redirected towards the PW, and the Scioto River within the stream reach adjacent to the PW was a losing stream (a stream reach where surface water recharges groundwater).

Table 3. Water levels in wells at the study area, Pickaway County, Ohio.

[ft, foot; elevations are referenced to North American Vertical Datum of 1988 (NAVD 88); PW, pumping well; dates for water-level data are in $\mathrm{mm} / \mathrm{dd} / \mathrm{yy}$ format]

\begin{tabular}{lcc}
\hline $\begin{array}{c}\text { Well } \\
\text { identifier }\end{array}$ & $\begin{array}{c}\text { Water level before } \\
\text { test on 10/23/12 } \\
\text { (ft) }\end{array}$ & $\begin{array}{c}\text { Water level at end } \\
\text { of test on 11/16/12 } \\
\text { (ft) }\end{array}$ \\
\hline 3H & 662.22 & 662.47 \\
6A & 663.98 & 663.14 \\
6C & 662.36 & 659.30 \\
OB1 & 662.22 & 661.63 \\
OB2 & 661.70 & 662.18 \\
P1 & 662.41 & 656.92 \\
P2 & 662.57 & 658.96 \\
P3 & 662.33 & 658.51 \\
PW & 662.30 & 632.73 \\
R1 & 662.36 & 656.60 \\
R2 & 662.34 & 654.54 \\
R3 & 662.34 & 657.55 \\
\hline
\end{tabular}




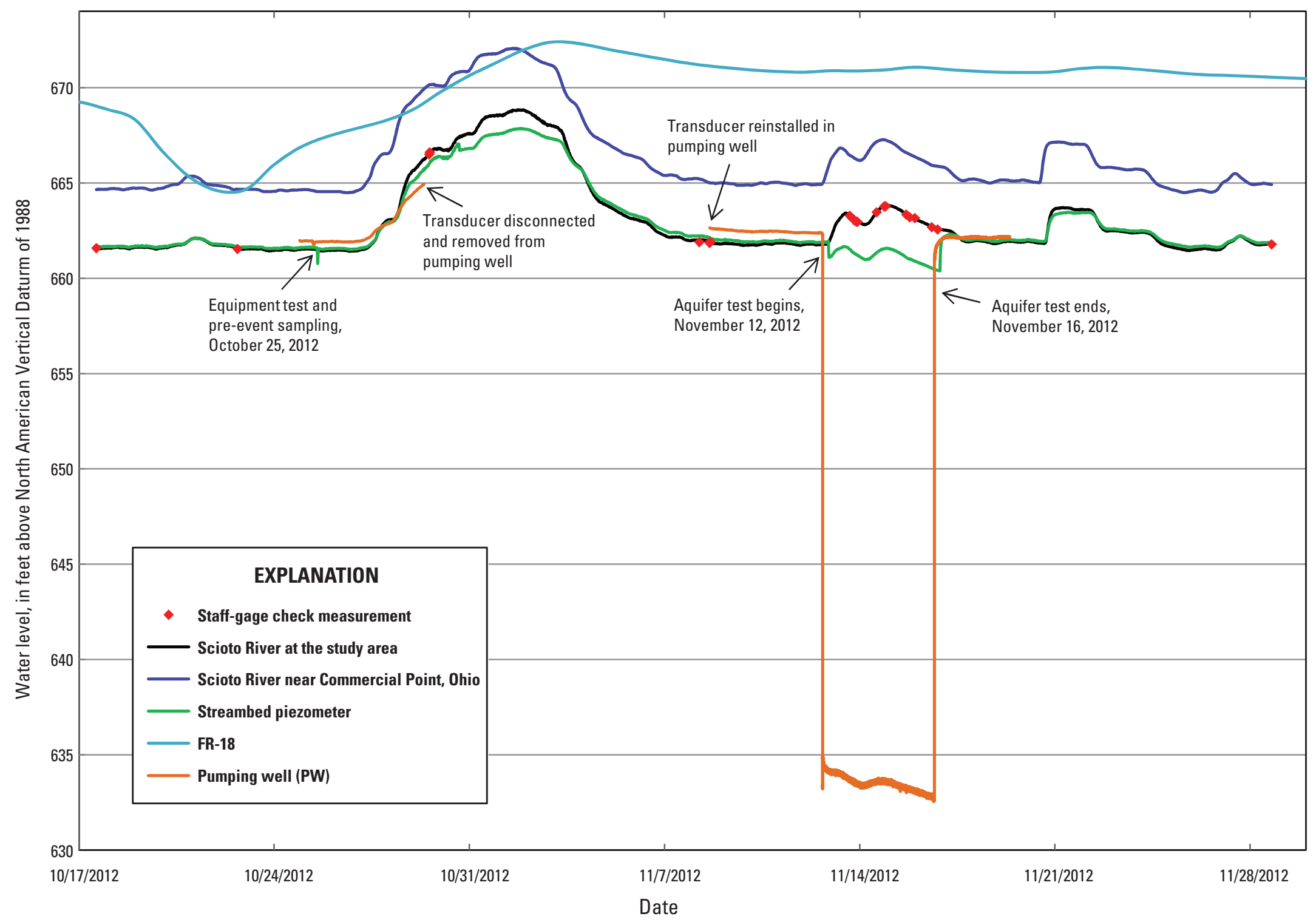

Figure 2. Hydrograph of groundwater and surface-water level altitudes at the study area and at sites upstream of the study area in Pickaway and Franklin Counties, Ohio, October and November 2012. 


\section{A. Water levels before the 96-hour aquifer test, November 12, 2012}
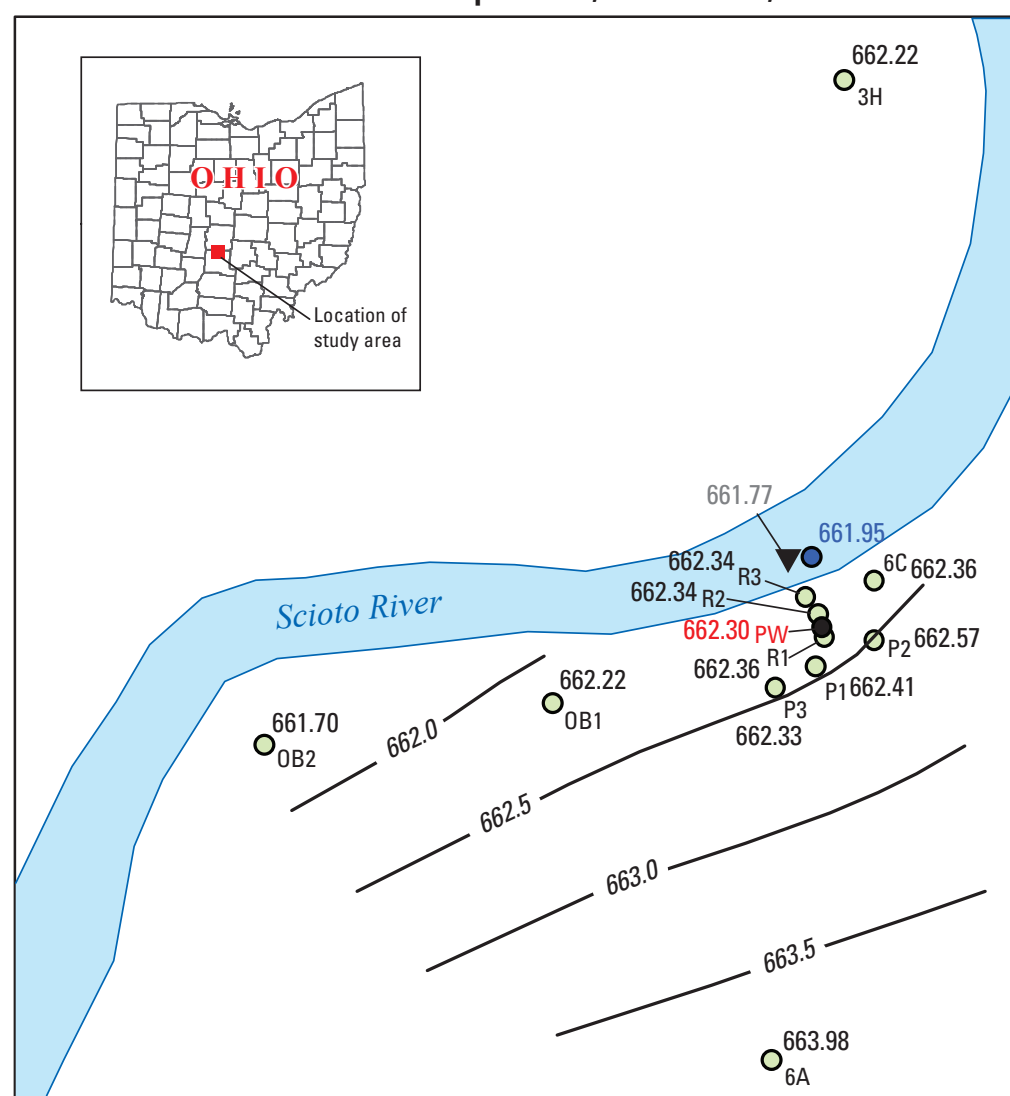

Base map from U.S. Geological Survey 1:24,000 topographic map, Commercial Point and Lockbourne 7.5-minute quadrangles, Datum is NAVD 88

\section{B. Water levels at the end of the 96-hour aquifer test, November 16, 2012}

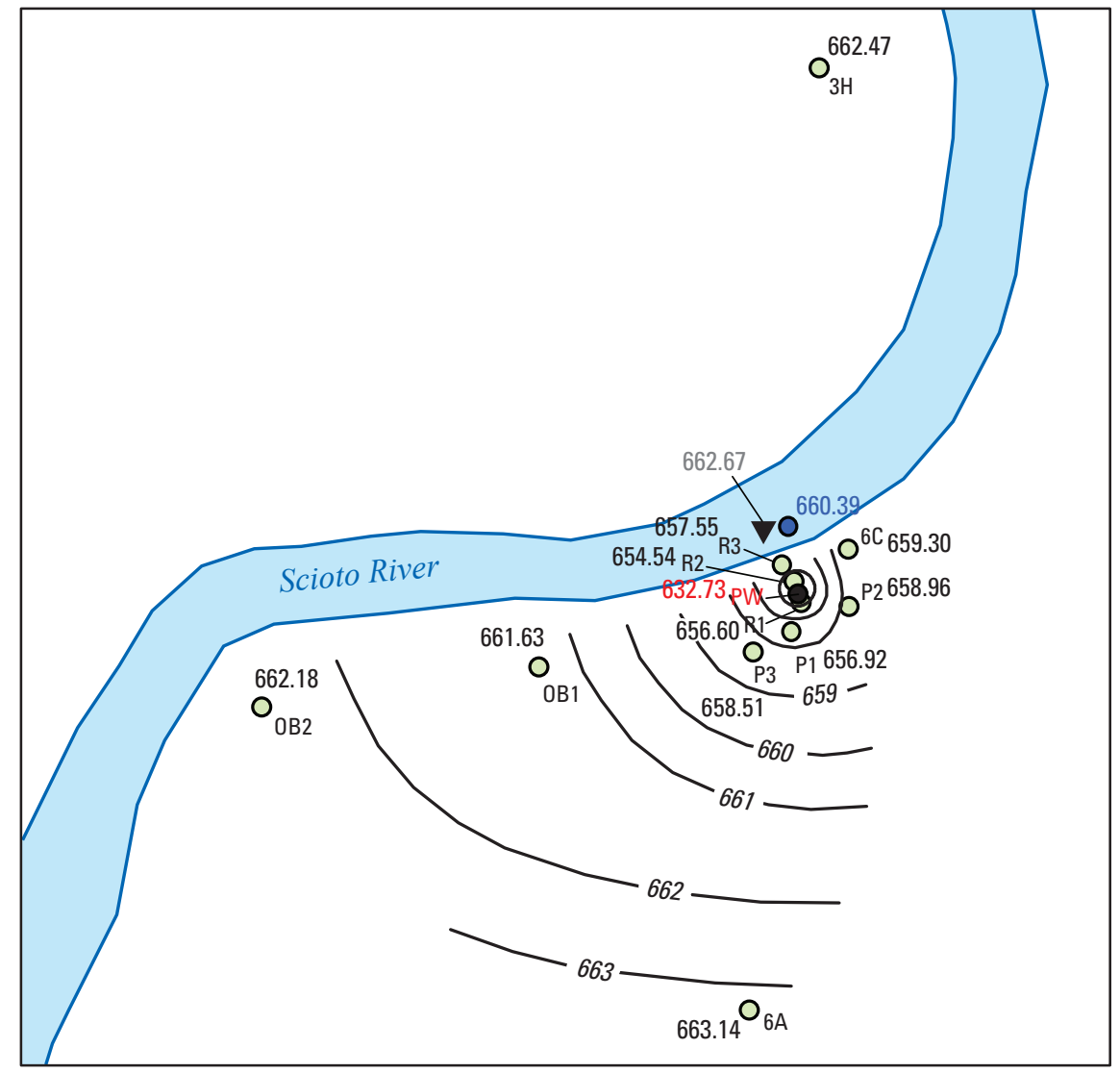

500 FEET

\section{$\begin{array}{lll}0 & 125 \quad 250\end{array}$}

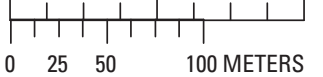

\section{EXPLANATION}

\begin{tabular}{|c|c|}
\hline $\mathrm{PW} \bullet 662.30$ & Pumping well, identifier, and water level \\
\hline${ }^{6 C} \mathrm{O} 662.36$ & Observation well, identifier, and water level \\
\hline $0^{661.95}$ & Streambed piezometer and water level \\
\hline $\boldsymbol{\nabla} 661.77$ & Staff gage and water level \\
\hline
\end{tabular}

Figure 3. Water levels at the study area, Pickaway County, Ohio, October and November 2012. $A$, Before the 96-hour aquifer test. $B$, At the end of the 96 -hour aquifer test. All elevations are referenced to the North American Vertical Datum of 1988 (NAVD 88). 
Water levels in all observation wells declined within the first minute in response to the onset of pumping. Maximum drawdown within the four observation wells sampled by the USGS ranged from 3.06 to $5.49 \mathrm{ft}$. The report by Bennett \& Williams Environmental Consultants, Inc. (2000), indicated silty clay layers beneath the sites at R3 and R2, but not in any of the other wells, including the PW. The geologic section shows the clay layers as continuous layers beneath the Scioto River, but additional data to confirm this were not available. Even though these wells are within the higher hydraulic conductivity zone described above, the presence of clay layers may influence the hydraulic connection between the river and underlying aquifer materials adjacent to wells R2 and R3.

\section{Water Quality}

Results of water-quality analyses are included in table 4 (a Microsoft Excel table available for download on the USGS Publications Warehouse site at http://pubs.usgs.gov/ sir/2014/5040/). Quality-control samples included a field blank collected at well R3 and a sequential replicate sample taken at well 6C. Concentrations of analytes in the blank sample were below the reporting limit, indicating field equipment used in sampling (including the sampling pump, discharge hose, and sampling tubes) caused no apparent contamination at the start of sampling (table 4). With the concurrent replicate sample, concentrations of available constituents were compared by computing a relative percent difference as follows:

$$
\text { Relative percent difference }=\left(\frac{\text { Replicate } 1-\text { Replicate } 2}{\frac{\text { Replicate } 1+\text { Replicate } 2}{2}}\right) \times 100
$$

where

Replicate 1 is the concentration of the analyte from the sample collected at 1500 hours at well 6C and

Replicate 2 is the concentration of the analyte from the quality-control sample collected at 1501 hours at well 6C.

For several constituents (bromide, ammonia, nitrite, and orthophosphate), concentrations of either or both the reported value and replicate value were at or near the reporting limit. For chloride, nitrate plus nitrite, and nitrate, the relative percent differences were less than 2 percent. Strontium and total nitrogen had relative percent differences of 3.43 and 5.92 percent, respectively. Stable isotopes of nitrogen and oxygen in nitrate had relative percent differences of -18.5 and -18.1 percent, respectively, but results of isotopic analyses are reported to be within 0.46 and 0.25 per mil and are within the "estimated expanded uncertainty" of 0.5 per mil as described by Coplen and others (2006). All of these quality-control results indicate that the water-quality data collected as part of this study for select constituents had acceptable variability; however, the few samples collected as part of this study shed some uncertainty on this assertion. To better understand the variability associated with the sampling and analytical methods used and the heterogeneity in the sampled water, many more quality-control samples would need to have been collected.

Figure 4 shows a series of plots with daily total rainfall and daily average air temperature from a weather station at Port Columbus Airport (National Oceanic and Atmospheric Administration, 2013) approximately $17 \mathrm{mi}$ northeast of the study site and water-quality information (including water temperature, specific conductance, dissolved oxygen, $\mathrm{pH}$, and turbidity) from the Scioto River at the USGS streamgage "03228039 Scioto River above Shadeville OH." Most of the field measurements obtained from the Scioto River at the study area (shown as black dots) plot at similar levels or concentrations as the continuous data obtained from the upstream gage; however, there are some exceptions where use of the upstream gage as a surrogate does not approximate waterquality conditions at the study area.

As shown on figure 4, daily average air temperature at Port Columbus Airport dropped from about 10 to 20 degrees Celsius $\left({ }^{\circ} \mathrm{C}\right)$ prior to October 24 and to about $5{ }^{\circ} \mathrm{C}$ after November 1. After November 1, surface-water temperatures at the streamgage dropped from about 14 to $17^{\circ} \mathrm{C}$ down to about $8{ }^{\circ} \mathrm{C}$. Surface-water temperature at the study area was $9.6^{\circ} \mathrm{C}$ on November 12 and decreased to $3.9^{\circ} \mathrm{C}$ on November 16 .

Field measurements of water temperature, specific conductance, dissolved oxygen, $\mathrm{pH}$, and turbidity from four observation wells were recorded on October 23 and again on November 16 (table 4). Groundwater temperatures generally differed by less than 1 degree between the two dates, but were cooler in wells $\mathrm{P} 3$ (8.7 and $7.7^{\circ} \mathrm{C}$, respectively) and $\mathrm{P} 1$ (8.6 and $8.2^{\circ} \mathrm{C}$, respectively) than in wells $\mathrm{R} 3\left(12.4\right.$ and $11.8^{\circ} \mathrm{C}$, respectively) and $6 \mathrm{C}\left(12.4\right.$ and $12.2^{\circ} \mathrm{C}$, respectively). Wells P3 and P1 are within the lower permeability zone described by Bennett \& Williams Environmental Consultants, Inc. (2000), whereas wells R3 and 6C are within the higher permeability zone. Groundwater temperatures decreased in all observation wells from October 23 to November 16. Groundwater temperature in the PW was $11.8^{\circ} \mathrm{C}$ on October 25 , and was slightly cooler at the onset of the aquifer test but steadily increased from $11.4{ }^{\circ} \mathrm{C}$ on November 13 to $12.0^{\circ} \mathrm{C}$ on November 16 (fig. 5). The study design proposed use of water temperature as an indicator of induced infiltration from the Scioto River; however, surface-water temperatures decreased during the aquifer test whereas groundwater temperature in the PW increased. Possible explanations for this inverse response include a lag effect between changes in surface-water and groundwater temperatures or a temperature increase resulting from heat generated by friction from the high-capacity pump installed in the PW. 

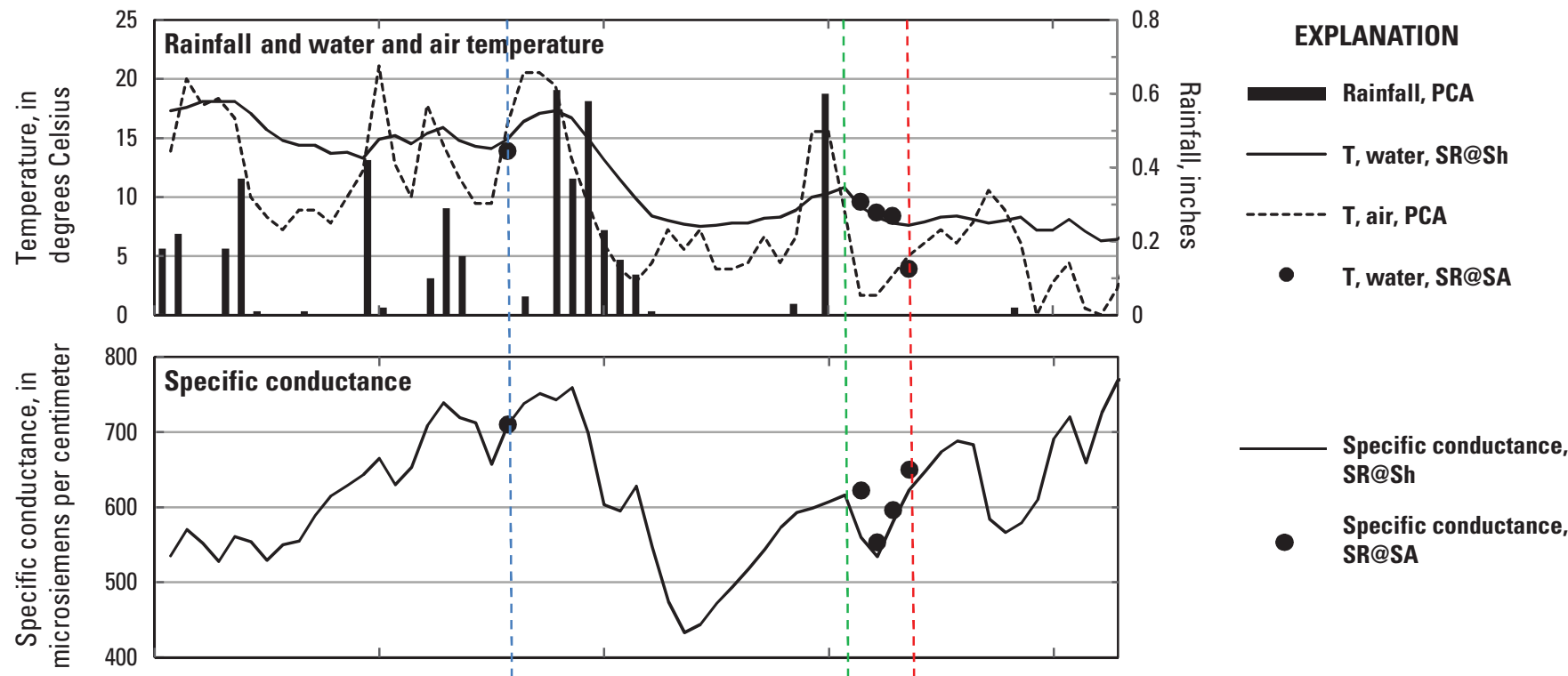
SR@Sh

Specific conductance, SR@SA

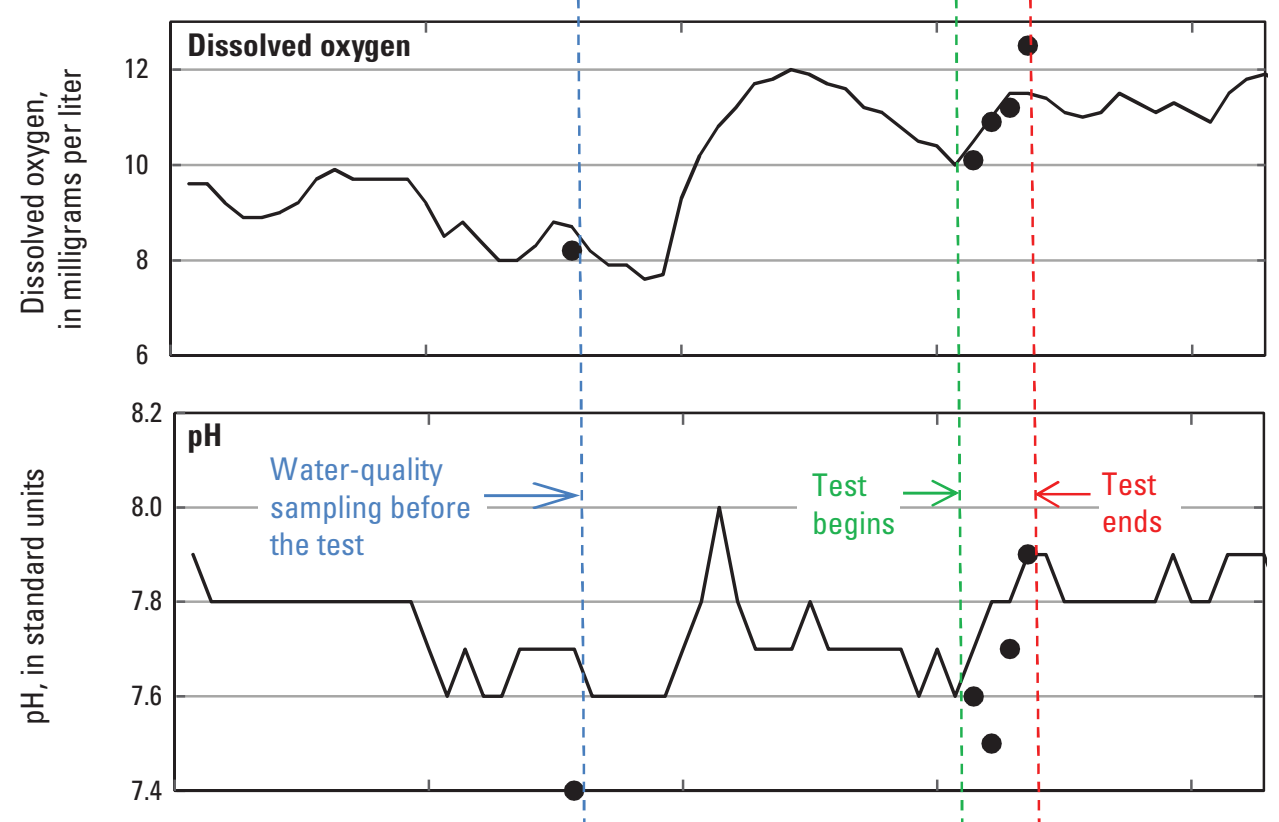

Dissolved oxygen, SR@Sh

Dissolved oxygen, SR@SA

pH, SR@Sh

pH, SR@SA

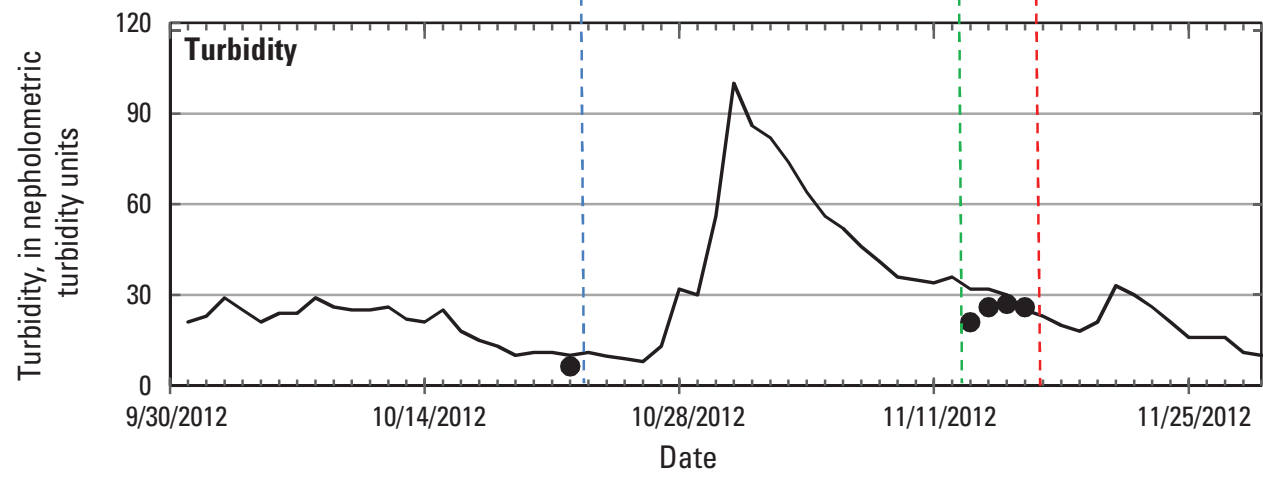

Turbidity, SR@Sh

Turbidity, SR@SA

Figure 4. Time-series plots of rainfall and air temperature at the Port Columbus Airport and water quality in the Scioto River, Ohio, October and November 2012. (T, temperature; PCA, Port Columbus Airport; SR@Sh, Scioto River at Shadeville; SR@SA, Scioto River at the study area) 

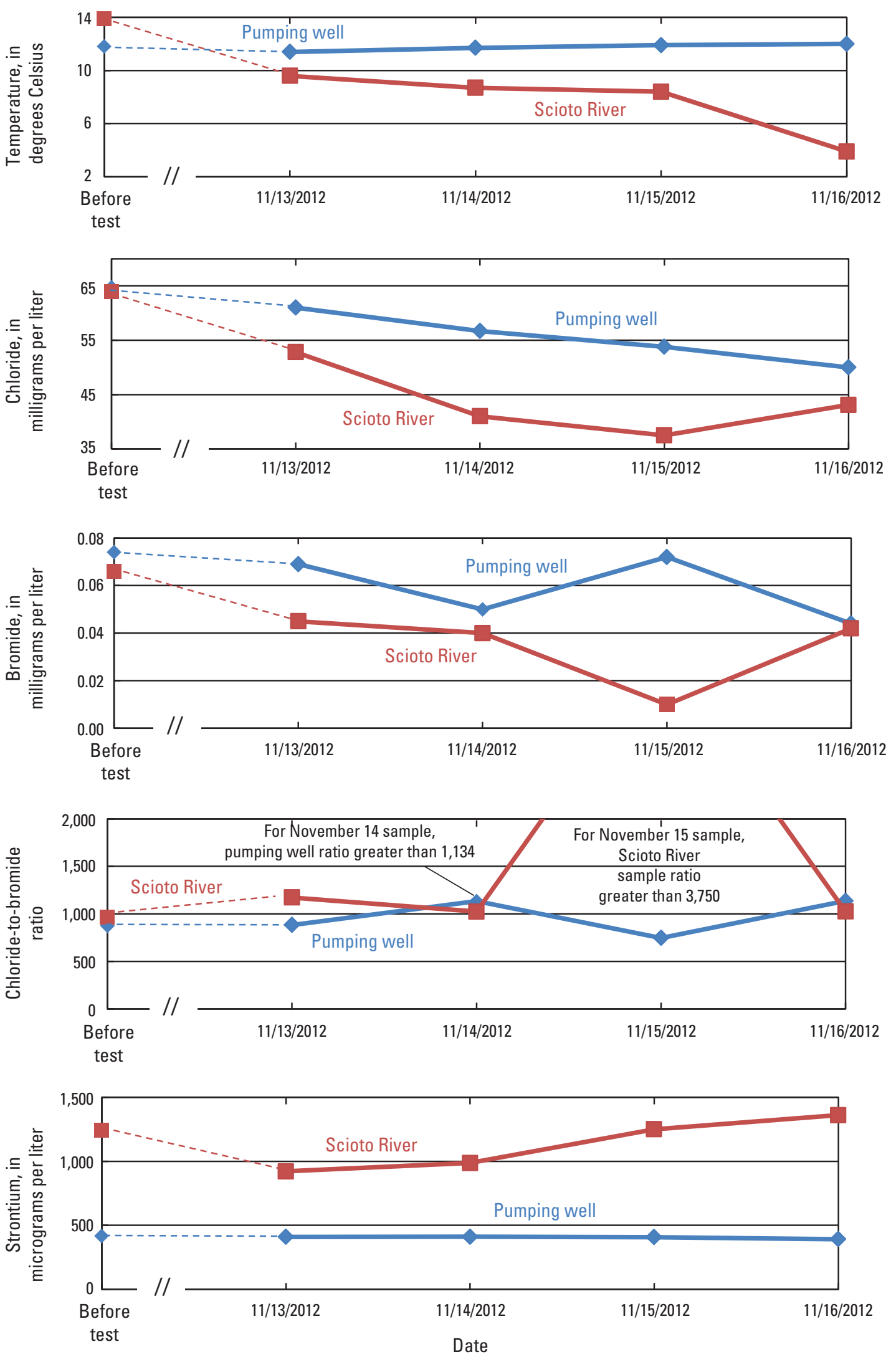

Figure 5. Water-quality results for temperature, chloride, bromide, chloride-to-bromide ratio, and strontium for samples from the pumping well and the Scioto River, Pickaway County, Ohio. "Before test" samples obtained October 25, 2012. 
Only minor variations in specific conductance, dissolved oxygen, $\mathrm{pH}$, and turbidity were observed between samples collected before and at the end of the aquifer test in groundwater samples obtained from the four observation wells. Specific conductance decreased slightly in samples from all four wells. Wells R3 and P1 had slightly higher specific conductance than wells $\mathrm{P} 3$ and $6 \mathrm{C}$, although these differences may be within measurement error of the instrument. Specific conductance values in the PW were similar to those in wells R3 and P1 and varied less than 20 microsiemens per centimeter at 25 degrees Celsius $\left(\mathrm{mS} / \mathrm{cm}\right.$ at $\left.25^{\circ} \mathrm{C}\right)$ throughout the entire 96 -hour test. Dissolved oxygen was lowest in well R3 $(0.1 \mathrm{mg} / \mathrm{L}$ before and at the end of the test) and highest in well P1 $(5.8 \mathrm{mg} / \mathrm{L}$ before the test and $4.7 \mathrm{mg} / \mathrm{L}$ at the end of the test). Dissolved oxygen concentrations in the PW remained relatively constant -2.0 to $2.2 \mathrm{mg} / \mathrm{L}$ before and throughout the test. $\mathrm{pH}$ also had only minor variations before and throughout the test, with the greatest variation of $0.5 \mathrm{pH}$ units observed in the PW. Turbidity was generally low (5.5 Formazin Nephelometric Units and 3.5 Nephelometric Turbidity Ratio Units or less ${ }^{1}$ ) in all groundwater samples, except for the first groundwater sample obtained from the PW (62 Formazin Nephelometric Units). Higher turbidities often are recorded at the onset of pumping from groundwater wells, when high pumping rates may disturb accumulated sediment in the well and (or) turbulent flow dislodges fine particles from the well screen, gravel pack, and (or) surrounding aquifer materials.

All major and trace-element concentration data were examined to determine if chemistry of water from the PW changed and approached that of the river. Major and traceelement analyses shown in table 4 from samples obtained from the Scioto River and the PW before and at the end of the 96-hour aquifer test generally indicate only small variations with time. Comparison of groundwater chemistry with surface-water chemistry from before and at the end of the test yielded inconsistent results. For example, small decreases were noted in concentrations of calcium and magnesium from groundwater samples from the PW before and at the end of the 96-hour aquifer test. Concentrations of calcium and magnesium in the river were consistently lower than those from the PW. Concentrations of potassium in groundwater from the PW were slightly greater (by about $0.2 \mathrm{mg} / \mathrm{L}$ ) at the end of the test than they were before the test. In general, concentrations of potassium were greater in the river than in the PW. Concentrations of potassium in the PW increased from the start of the test to the end of the test, while concentrations of potassium in the river decreased from the start of the test to the end of the test (table 4). Sodium concentrations were lower in samples from the PW than in the river before the test. Concentrations of sodium in river water decreased during the test and were consistently higher than those in samples from the PW. These results indicate that calcium, magnesium, and potassium

\footnotetext{
${ }^{1}$ Turbidity data were collected by two different methods and are reported as Formazin Nephelometric Units (infrared light source) and Nephelometric Turbidity Ratio Units (white light source).
}

concentrations in samples from the PW were either decreasing or increasing towards concentrations observed in the river, but sodium concentrations were not. Ultimately, interpretation of these data is confounded by having a significant hydrologic event occur between the date the samples were initially collected and the date the aquifer test was done combined with the limitations of a small sample size. Time and funding constraints prohibited the study team from collecting another set of samples before the start of the test.

Additional samples for chloride, bromide, and strontium were obtained from the Scioto River and the PW during the aquifer test on November 13, 14, 15, and 16, 2012. Figure 5 shows that the concentrations of chloride and bromide in samples obtained before the test (October 22 and 25) from both the Scioto River and PW were generally higher than those obtained during the aquifer test (November 13-16). Chloride concentrations generally decreased in samples from the river and PW throughout the aquifer test. For samples of groundwater obtained from the observation wells, chloride concentrations were lower in three out of four of the sampled wells (wells R3, P1, and 6C; table 4) towards the end of the test as compared to before the test. Bromide concentrations for one well (P1) were substantially lower towards the end of the test as compared to before the test; whereas concentrations from the other three observation wells were at or near the reporting limits (reporting limits varied from less than $0.010 \mathrm{mg} / \mathrm{L}$ to less than $0.050 \mathrm{mg} / \mathrm{L}$ in four samples) or included estimated concentrations (denoted with an "E" in table 4). Strontium concentrations in the Scioto River on October 25 were higher than those measured during the first day of the aquifer test; however, strontium concentrations in the river steadily increased from November 13 to November 16. Strontium concentrations were relatively consistent in the PW and only displayed a small decline of 25 micrograms per liter $(\mu \mathrm{g} / \mathrm{L})$ from before and towards the end of the aquifer test.

Ratios of chloride to bromide were examined to determine the source of these elements to groundwater and surface water (table 4 and fig. 5). For the purposes of this analysis, bromide concentrations that were estimated (denoted with an "E" in table 4) or those below the detection limit were used in the computation of the ratio at the estimated or "greaterthan" value. Chloride-to-bromide ratios for all samples ranged from 718 to greater than 3,750. Oblinger and others (1991) sampled surface water and groundwater in the vicinity of the South Well Field in Franklin County and reported chloride-tobromide ratios that ranged from 155 to 1,060 in wells screened within glacial sediments; 180 to 292 in the public-supply wells (also screened in the glacial sediments); 86 to 1,500 in bedrock wells; and 53 for a sample of Scioto River water. Davis and others (1998) established that chloride-to-bromide ratios in the range of 1,000 to 10,000 were indicative of waters influenced by dissolution of halite. Except for the Scioto River 
sample collected on November 15, 2012, chloride-to-bromide ratios were about 1,000 and were relatively consistent in water samples from the PW and Scioto River (fig. 5). Potential halite sources in the study area include evaporites in the carbonate bedrock and (or) road salt.

Of specific interest to the City were concentrations of nitrate (reported in $\mathrm{mg} / \mathrm{L}$ as $\mathrm{N}$ ) in groundwater in the $\mathrm{PW}$ in relation to those in the Scioto River and in adjacent observation wells. Total nitrogen (the sum of all nitrogen species) in water samples obtained during this study was dominated by nitrate. Nitrate concentrations in water from the PW were highest on October 25 (before the test began) at $5.42 \mathrm{mg} / \mathrm{L}$ and were lowest on November 13 (during the first day of pumping) at $5.10 \mathrm{mg} / \mathrm{L}$. Within the Scioto River, nitrate concentrations varied from $4.97 \mathrm{mg} / \mathrm{L}$ on October 22 to $3.46 \mathrm{mg} / \mathrm{L}$ during the second day of pumping (November 14). No consistent upward or downward trends in nitrate were observed within the observation period in the PW; however, concentrations of nitrate were higher in the Scioto River at the end of the test $(4.80 \mathrm{mg} / \mathrm{L})$ than they were at the beginning $(3.56 \mathrm{mg} / \mathrm{L}$; fig. 6).
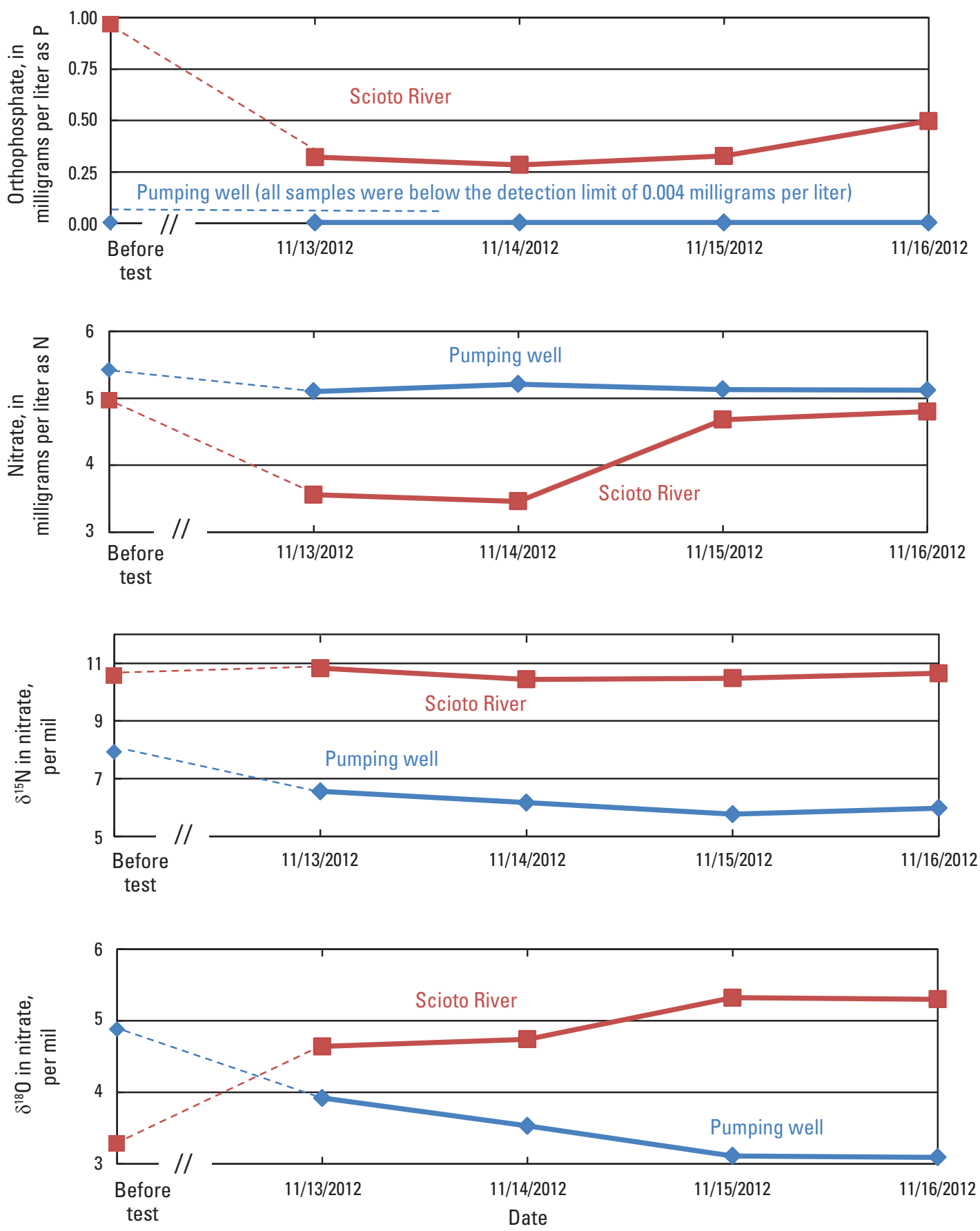

Figure 6. Waterquality results for orthophosphate, nitrate, $\delta^{15} \mathrm{~N}$ in nitrate, and $\delta^{18} 0$ in nitrate for samples from the pumping well and the Scioto River, Pickaway County, Ohio. “Before test" samples obtained October 25, 2012. 
Nitrate concentrations were highest in groundwater samples from observation wells $\mathrm{P} 1$ and $6 \mathrm{C}$ before the onset of pumping ( 7.86 and $9.31 \mathrm{mg} / \mathrm{L}$, respectively). Concentrations decreased by 0.45 and $0.83 \mathrm{mg} / \mathrm{L}$, respectively, in those wells from the October 23 to the November 16 sampling dates. Concentrations of nitrate in groundwater from well R3 decreased from 3.38 to $0.14 \mathrm{mg} / \mathrm{L}$; whereas concentrations in well P3 increased from 0.53 to $4.94 \mathrm{mg} / \mathrm{L}$ during this time period. These changes in nitrate concentrations indicate that, as pumping commenced, the sources of water to well R3 changed to provide water with less nitrate, while the sources of water to well P3 changed to provide water with more nitrate.

Other nutrients, including ammonia and organic nitrogen, were at or below reporting limits in all PW and observation-well samples (table 4). Nitrite was detected above the reporting limit of $0.003 \mathrm{mg} / \mathrm{L}$ in the $\mathrm{PW}$, observation well R3, and the Scioto River in all sampling events. Orthophosphate (reported in $\mathrm{mg} / \mathrm{L}$ as phosphorus) was detected above the reporting limit of $0.004 \mathrm{mg} / \mathrm{L}$ in well P3 only before the pumping started, in well $6 \mathrm{C}$ before and at the end of the pumping, and in the Scioto River during all sampling events. Orthophosphate was below the reporting limits of $0.004 \mathrm{mg} / \mathrm{L}$ in all samples obtained from the PW and wells R3 and P1. Wells P3 and 6C had one and two samples, respectively, with detections of $0.005 \mathrm{mg} / \mathrm{L}$ (just slightly above the reporting limit). All samples from the Scioto River had detectable concentrations of orthophosphate as phosphorus, ranging from 0.284 to $0.968 \mathrm{mg} / \mathrm{L}$, indicating the river is a potential source of orthophosphate to groundwater.

Isotope ratios of nitrogen $\left(\delta^{15} \mathrm{~N}\right)$ and oxygen $\left(\delta^{18} \mathrm{O}\right)$ in nitrate were measured in water samples to evaluate the source of nitrate in groundwater and surface water. Isotope ratios for samples collected at the study area were plotted in relation to ratios that have been documented for different nitrate sources by Kendall and others (2007; fig. 7). The data collected at the study area indicate that the source of nitrate in groundwater is mostly soil nitrogen and fertilizer, with the slope of the data points on the graph reflecting denitrification and (or) mixing with some manure and septic waste. Concentrations of organic nitrogen below the reporting limit (table 4) indicate that soil nitrogen and fertilizer were the dominant source of nitrate in this setting. The isotope ratios in nitrate from the Scioto River are slightly enriched in comparison to those in groundwater and likely include septic waste from upstream wastewatertreatment facilities. The range of nitrogen- and oxygen-isotope ratios for surface-water and groundwater samples illustrates mixing of nitrogen sources and interpretation of the source(s) of water to the PW on the basis of isotopes is confounded by this mixing phenomenon as well as denitrification.

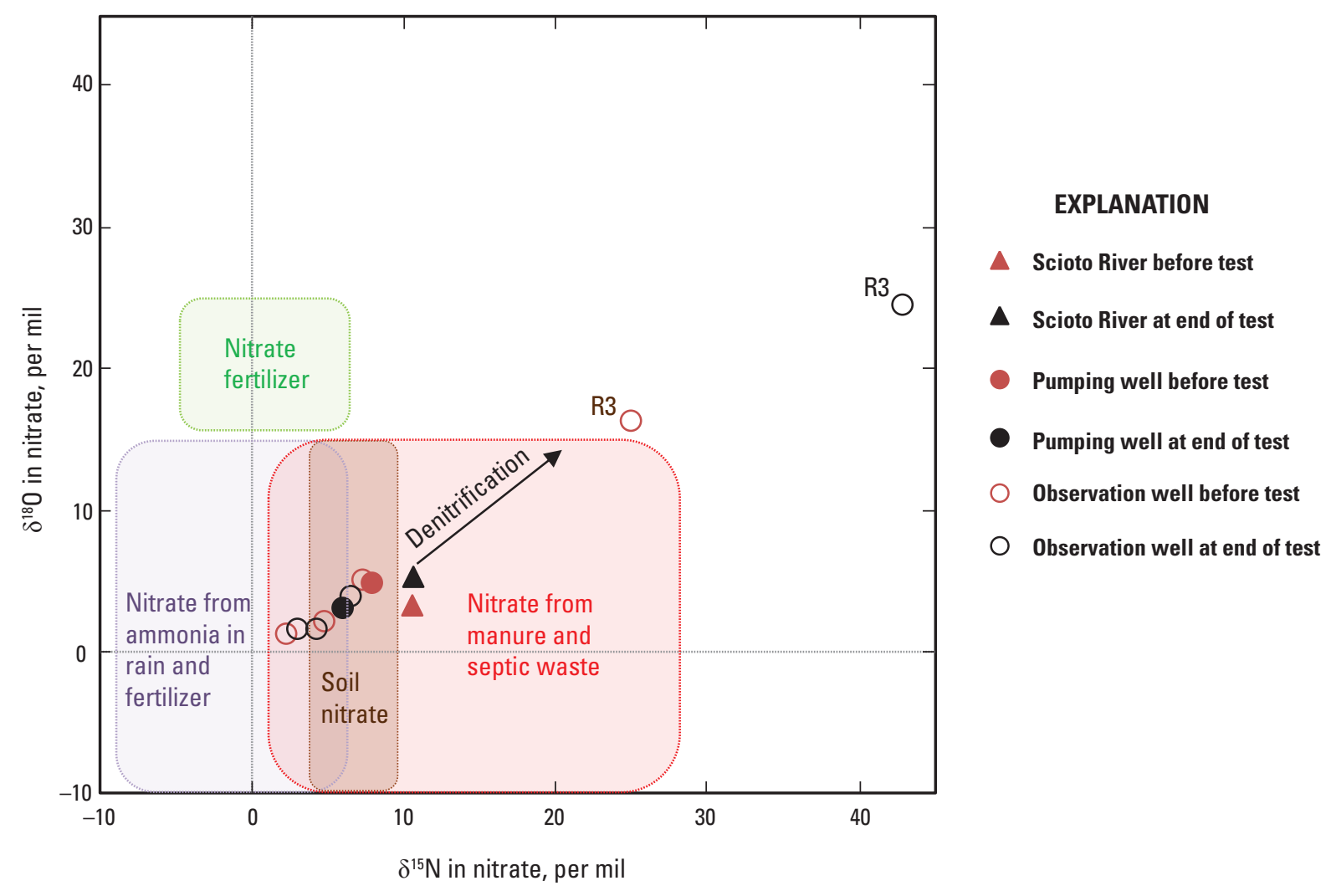

Figure 7. Stable-isotope ratios of nitrogen and oxygen in nitrate from water samples obtained before and during the aquifer test, Pickaway County, Ohio, October and November 2012. (Pretest sample from the Scioto River was obtained on October 22; pretest samples from observation wells were obtained 0 ctober 23; pretest sample from the pumping well was obtained October 25. Shaded fields modified from Kendall and others, 2007.) 
The isotopic signature of nitrate of water samples from well R3 was relatively enriched in the heavier isotopes of both nitrogen and oxygen and was quite different than any other samples $\left(\delta^{15} \mathrm{~N}\right.$ was +24.97 and $\delta^{18} \mathrm{O}$ was +16.35 per mil, respectively, before the test began). The samples from this well also had low dissolved oxygen and the highest concentration of nitrite before pumping began. Towards the end of the test, both the nitrogen- and oxygen-isotope ratios were greater than those measured before the test began. Although the reason for the increase in isotope ratios is unclear, hydraulic isolation from the rest of the silty sand and gravel deposits at the site has likely created reducing conditions as demonstrated by low dissolved oxygen and elevated nitrite concentrations and denitrification of groundwater obtained from well R3.

\section{Limitations of the Current Study}

Based on the results of this and previous studies, the source of water to the PW is likely a mix of groundwater and water captured from the river. The relative proportions of each cannot be determined without further detailed analysis. Likewise, results of the water-quality analysis were inconclusive in determining whether or not the potential supply well would produce waters with elevated nitrate concentrations with continued pumping.

This study was done with limited resources and time. To determine if concentrations of nitrate in water from the pumping well (PW) would change as a result of continued pumping and (or) induced infiltration of river water, longer-term study is needed of natural variations in the water quality of the river and of groundwater under natural and stressed (pumping) conditions. A detailed water-temperature study to allow tracing of surface-water contribution to the PW could include additional monitoring points and evaluation of lag times between temperatures observed in the river and temperatures observed in groundwater. Ideally, the temperature study should occur when surface-water temperatures are at their annual maximum (late summer). Additionally, other tracers, including tritium/helium, could be used to date the groundwater to determine the time since recharge of these waters to gain further understanding of the likelihood of water-quality changes in response to landuse changes. Groundwater-flow modeling using parameter estimation and (or) optimization techniques also could help in determining locations for additional data collection and understanding of sources of water to the PW. Lastly, additional quality-control samples would help to assess the uncertainty associated with variability in the sample medium as well as the analytical techniques.

\section{Summary and Conclusions}

A 96-hour aquifer test was performed at a study area in Pickaway County, Ohio, by the City of Columbus to document water levels and examine the potential for water-quality changes as pumping progressed. Water levels in all wells responded soon after pumping commenced. Maximum drawdown of 29.75 feet (ft) in the PW was measured towards the end of the test. Water levels in a nearby streambed piezometer began to decline after about 180 minutes of pumping, reaching a maximum drawdown of $2.29 \mathrm{ft}$ approximately 67 hours after pumping began. Before the test, groundwater-flow directions at the study area were towards the Scioto River, and the river was a gaining stream. Towards the end of the test, groundwater-flow directions at the study area were towards the PW, and the Scioto River was a losing stream.

The water-quality data provide several explanations for understanding the sources of water to the PW. The investigation included analysis of water samples to evaluate sources of water to a PW, including temperature, nitrate, chloride, bromide, strontium, stable isotopes of nitrogen and oxygen in nitrate, and several other properties and constituents. Air and surface-water temperatures decreased during the test while groundwater temperatures increased as recorded in the discharge from the PW. Nitrate (the dominant form of nitrogen in all samples) in water from the PW was measured at concentrations from 5.10 to 5.42 milligrams per liter $(\mathrm{mg} / \mathrm{L})$. Nitrate concentrations in the Scioto River were 1 to $2 \mathrm{mg} / \mathrm{L}$ lower than those observed in the PW and increased by more than $1 \mathrm{mg} / \mathrm{L}$ during the test. The highest nitrate concentrations were obtained from groundwater samples from wells P1 and 6C before the onset of pumping (nitrate concentration in well 6C on October 23, 2012, was $9.31 \mathrm{mg} / \mathrm{L}$, which is just under the $10 \mathrm{mg} / \mathrm{L}$ U.S. Environmental Protection Agency's Maximum Contaminant Level). Nitrate concentrations remained steady in samples from most wells and in the Scioto River throughout the test; however, nitrate concentrations in well R3 decreased while concentrations in well P3 increased before and towards the end of the test. Chloride concentrations generally decreased in samples from the river and the PW throughout the aquifer test, and from observation wells R3, P1, and 6C before and at the end of the aquifer test. Bromide concentrations in samples from well P1 decreased; whereas bromide in other samples increased or remained nearly the same. The chloride-to-bromide ratios for the Scioto River and the PW remained relatively consistent at about 1,000 , which is indicative of halite sources derived from evaporites in bedrock and (or) road salt, except for the sample obtained on November 15, 2012. Strontium concentrations in the Scioto River steadily increased from November 13 to November 16, but remained relatively consistent in the $\mathrm{PW}$. Isotope ratios of nitrogen and oxygen in nitrate revealed that the source of nitrate in groundwater is most likely soil nitrogen and fertilizer; whereas the source of nitrate in the Scioto River is manure and septic waste. The nitrate in some of the samples appears to have undergone denitrification, as shown by the linear trend on a graph of nitrogen and oxygen isotopes in nitrate.

Before and during the aquifer test, conditions in the Scioto River changed, especially in regards to streamflow and temperature, but groundwater quality within the PW remained relatively constant. Even with the large variation 
in weather conditions before and during the test, water-level data and chemical analyses demonstrated the heterogeneity of the alluvial and glacial sediments at the study area. Comparison of data collected at the site with data from two upstream streamgages and one observation well indicates that surrogate data-collection sites that are miles away, but still in similar hydrogeologic settings, may provide only limited information towards the understanding of hydrologic conditions at the study site.

\section{References Cited}

Bennett \& Williams Environmental Consultants, Inc., 2000, Final report-Hydrogeologic investigation of the South Well Field Expansion Project: Columbus, Ohio, Bennett \& Williams Environmental Consultants, Inc., unpublished report prepared for the City of Columbus, $152 \mathrm{p}$.

Coplen, T.B., Brand, W.A., Gehre, Matthias, Gröning, Manfred, Meijer, H.A.J., Toman, Blaza, and Verkouteren, R.M., 2006, New guidelines for $\delta^{13} \mathrm{C}$ measurements: Analytical Chemistry, v. 78, no. 7, p. 2439-2441.

Coplen, T.B., Qi, Haiping, Révész, Kinga, Casciotti, Karen, and Hannon, J.E., 2012, Determination of the $\delta^{15} \mathrm{~N}$ and $\delta^{18} \mathrm{O}$ of nitrate in water; RSIL lab code 2900, chap. 17 of Stable isotope-ratio methods, sec. C of Révész, Kinga, and Coplen, T.B. eds., Methods of the Reston Stable Isotope Laboratory (slightly revised from version 1.0 released in 2007): U.S. Geological Survey Techniques and Methods, book 10, 35 p., available only at $h t t p: / / p u b s . u s g s . g o v / t m / 2006 /$ tm 10c17/. (Supersedes version 1.0 released in 2007.)

Cunningham, W.L., and Schalk, C.W., comps., 2011, Groundwater technical procedures of the U.S. Geological Survey: U.S. Geological Survey Techniques and Methods 1-A1, 151 p. (available only online at $h t t p: / / p u b s . u s g s . g o v /$ $\mathrm{tm} / \mathrm{lal} /$ )

Davis, S.N., Whittemore, D.O., and Fabryka-Martin, J., 1998, Uses of chloride/bromide ratios in studies of potable water: Ground Water, v. 36, no. 2, p. 338-350.

Fishman, M.J., and Friedman, L.C., 1989, Methods for determination of inorganic substances in water and fluvial sediments: U.S. Geological Survey Techniques of WaterResources Investigations, book 5, chap. A1, 545 p.

Fishman, M.J., ed., 1993, Methods of analysis by the U.S. Geological Survey National Water Quality Laboratory-Determination of inorganic and organic constituents in water and fluvial sediments: U.S. Geological Survey Open-File Report 93-125, 217 p.
Kendall, C., Elliott, E.M., and Wankel, S.D., 2007, Tracing anthropogenic inputs of nitrogen to ecosystems, Chapter 12, in Michener, R.H., and Lajtha, K., eds., Stable Isotopes in ecology and environmental science ( $2 \mathrm{~d}$ ed.): Malden, Mass., Blackwell Publishing, p. 375-449.

National Oceanic and Atmospheric Administration, 2013, National Climatic Data Center, Climate Data Online, accessed August 9, 2013, at http://cdo.ncdc.noaa.gov/ulcd/ $U L C D$.

Oblinger, C.J., Sheets, R.A., and Bair, E.S., 1991, Hydrology and water quality near the South Well Field, southern Franklin County, Ohio, with emphasis on the simulation of ground-water flow and transport of Scioto River: U.S. Geological Survey Water-Resources Investigations Report 91-4080, 78 p., accessed March 5, 2014, at http://pubs. er.usgs.gov/publication/wri914080.

Ohio Department of Natural Resources, 1995, Ground Water \& NPS-Mad River NPS Project Background and Results, accessed February 4, 2014, at http://www.dnr.state.oh.us/ water/maptechs/npsrpts/madriver/tabid/3787/Default.aspx.

Ohio Environmental Protection Agency, 2008, 2008 305(b) Report-Ohio's Ground Water Quality, accessed January 24, 2014, at http://www.epa.ohio.gov/portals/28/ documents/gwqcp/2008_305b.pdf.

Patton, C.J., and Kryskalla. J.R., 2003, Methods of analysis by the U.S. Geological Survey National Water Quality Laboratory-Evaluation of alkaline persulfate digestion as an alternative to Kjeldahl digestion for determination of total and dissolved nitrogen and phosphorus in water: U.S. Geological Survey Water-Resources Investigations Report 03-4174, 33 p.

Sauer, V.B., and Turnipseed, D.P., 2010, Stage measurement at gaging stations: U.S. Geological Survey Techniques and Methods book 3, chap. A7, 45 p. (Also available at $h t t p: / /$ pubs.usgs.gov/tm/tm3-a7/.)

Schumann, T.L., and Pletsch, B.A., 2006, Evaluation of nitrate concentrations and sources in the Elk Creek watershed, southwestern Ohio, 2003-2004: U.S. Geological Survey Scientific Investigations Report 2006-5223, 30 p.

U.S. Environmental Protection Agency, 2013, Drinking Water Contaminants - National Primary Drinking Water Regulations, accessed June 13, 2013, at http://water.epa.gov/drink/ contaminants/index.cfm.

U.S. Geological Survey, variously dated, National field manual for the collection of water-quality data: U.S. Geological Survey Techniques of Water-Resources Investigations, book 9, chaps. A1-A9, available online at http://pubs.water. usgs.gov/twri9A. 
Publishing support provided by the U.S. Geological Survey Science Publishing Network,

Columbus Publishing Service Center

For more information concerning the research in this report, contact the

Director, Ohio Water Science Center

U.S. Geological Survey

6480 Doubletree Avenue

Columbus, $\mathrm{OH}$ 43229-1111

http://oh.water.usgs.gov/ 
